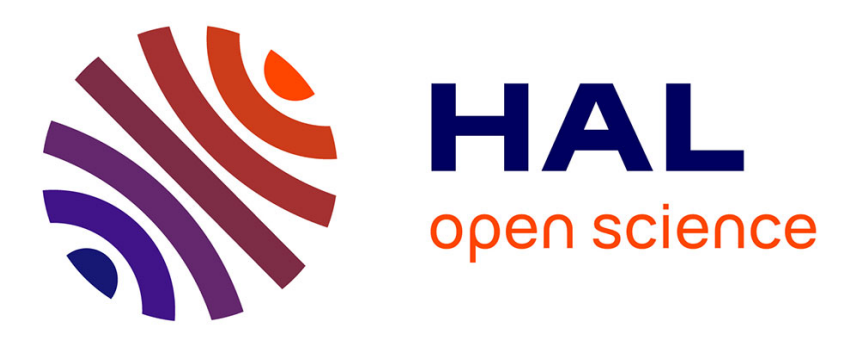

\title{
Degradation of native and exotic riparian plant leaf litter in a floodplain pond
}

Marion Bottollier-Curtet, Jean-Yves Charcosset, Anne-Marie Planty-Tabacchi, Eric Tabacchi

\section{- To cite this version:}

Marion Bottollier-Curtet, Jean-Yves Charcosset, Anne-Marie Planty-Tabacchi, Eric Tabacchi. Degradation of native and exotic riparian plant leaf litter in a floodplain pond. Freshwater Biology, 2011, vol. 56, pp. 1798-1810. 10.1111/j.1365-2427.2011.02620.x . hal-00955408

\section{HAL Id: hal-00955408 https://hal.science/hal-00955408}

Submitted on 4 Mar 2014

HAL is a multi-disciplinary open access archive for the deposit and dissemination of scientific research documents, whether they are published or not. The documents may come from teaching and research institutions in France or abroad, or from public or private research centers.
L'archive ouverte pluridisciplinaire HAL, est destinée au dépôt et à la diffusion de documents scientifiques de niveau recherche, publiés ou non, émanant des établissements d'enseignement et de recherche français ou étrangers, des laboratoires publics ou privés. 


\section{OATAO \\ Open Archive Toulouse Archive Ouverte}

\section{Open Archive TOULOUSE Archive Ouverte (OATAO)}

OATAO is an open access repository that collects the work of Toulouse researchers and makes it freely available over the web where possible.

This is an author-deposited version published in : http://oatao.univ-toulouse.fr/ Eprints ID : 8909

To link to this article : doi:10.1111/j.1365-2427.2011.02620.x

URL : http://dx.doi.org/10.1111/j.1365-2427.2011.02620.x

To cite this version : Bottollier-Curtet, Marion and Charcosset, JeanYves and Planty-Tabacchi, Anne-Marie and Tabacchi, Eric Degradation of native and exotic riparian plant leaf litter in a floodplain pond. (2011) Freshwater Biology, vol. 56 (n 9). pp. 1798-1810. ISSN 0046-5070

Any correspondance concerning this service should be sent to the repository administrator: staff-oatao@ listes-diff.inp-toulouse.fr 


\title{
Degradation of native and exotic riparian plant leaf litter in a floodplain pond
}

\author{
MARION BOTTOLLIER-CURTET ${ }^{*}{ }^{+}$, JEAN-YVES CHARCOSSET ${ }^{*}{ }^{+}$, ANNE-MARIE PLANTY- \\ TABACCHI ${ }^{*,+}$ AND ERIC TABACCHI ${ }^{*}+$ \\ *Laboratoire d'écologie fonctionnelle (EcoLab), Université de Toulouse 3, 118 route de Narbonne, Toulouse Cedex 9, France \\ ${ }^{\dagger}$ CNRS, Laboratoire d'écologie fonctionnelle (EcoLab), Toulouse, France
}

\section{SUMMARY}

1. A litter-bag experiment was undertaken in a pond on the margins of a large temperate floodplain in south-western France to assess the potential influence of the replacement of native by exotic riparian species on organic matter degradation. We determined initial litter chemical composition, breakdown rates and the invertebrate assemblages associated with the litter for five pairs of native dominant and exotic invasive species co-occurring at different stages along a successional gradient.

2. Litter chemical composition, breakdown rates and abundance and diversity of detritivorous invertebrates were similar for the exotic and native species overall. No overall changes in organic matter degradation can thus be predicted from the replacement of dominant natives by exotic invasives. Breakdown rates were primarily driven by the $\mathrm{C} / \mathrm{N}$ ratio.

3. One invasive species (Buddleja davidii) showed significantly higher breakdown rates than its native counterpart (Populus nigra), resulting in the disappearance of leaf litter 6 months prior to the next litterfall. In some cases, therefore, invasion by exotic species may result in discontinuity of resource supply for decomposers.

Keywords: decomposition, floodplains, invasive species, invertebrates, ponds

\section{Introduction}

Plant litter breakdown is a fundamental ecological process that affects nutrient cycling, nutrient availability and consequently organic matter production in both aquatic and terrestrial ecosystems (Swift, Heal \& Anderson, 1979; Webster \& Benfield, 1986; Xiong \& Nilsson, 1999). In riparian zones, litter produced by terrestrial plants is an important source of organic matter for the associated freshwater environments through direct input (Cummins et al., 1989; Thorp \& Delong, 1994; Langhans, 2006) or terrestrial litter

Correspondence: Marion Bottollier-Curtet, Laboratoire d'écologie fonctionnelle, Université de Toulouse 3, 118 route de Narbonne, F-31062 Toulouse Cedex 9, and CNRS, Ecolab, F-31062 Toulouse, France.

E-mail: m.bottollier.curtet@gmail.com redistribution by recurrent flooding (Xiong \& Nilsson, 1997; Langhans, 2006). Litter breakdown is mainly controlled by climate (Hanson et al., 1984; Coûteaux, Bottner \& Berg, 1995), litter chemical quality (Cadish \& Giller, 1997; Ostrofsky, 1997) and microbes and detritivorous animals (Petersen \& Luxton, 1982; Hieber \& Gessner, 2002). Microbial decomposition of litter enhances the attractiveness of leaf detritus to detritivores that can degrade up to $50 \%$ of the annual litter input into lotic ecosystems (Cuffney, Wallace \& Lugthart, 1990; Hieber \& Gessner, 2002). In temperate ecosystems, seasonal litterfall results in a sharp decrease in breakdown activity from autumn to the end of summer. However, late leaf abscission of some plant species and the persistence of slowly degrading litter can maintain resource continuity for microbes and detritivores until the next autumn (Staelens et al., 2011). 
As a result of worldwide transport by humans, coupled with hydrological disturbance and high landscape connectivity, exotic plants can represent on average more than $20 \%$ of plant species inhabiting temperate riparian ecosystems (Planty-Tabacchi et al., 1996; Stohlgren et al., 1998; Richardson et al., 2007). The highly diverse mosaic of habitats that characterises riparian areas of floodplains may support a wide diversity of invasive species (PlantyTabacchi et al., 1996; Schnitzler, Hale \& Aslum, 2007). Such invasive species can be responsible for marked changes in community structure and ecosystem functioning (Vitousek et al., 1996; Ehrenfeld, 2010). Two main hypotheses have been proposed to account for differences in breakdown rates among native plants and the exotic species that may replace them. The first hypothesis relates to the distinctive traits of invasives that makes them more efficient in resource uptake and in the production of biomass with higher nutrient concentrations, especially of $\mathrm{N}$ and $\mathrm{P}$ (Alpert, 2006; Leishman et al., 2007; Liao et al., 2008). Thus, it has been suggested that litter from exotic species will degrade faster than that from natives (Ehrenfeld, 2003; Ashton et al., 2005). The second hypothesis refers to the lack of co-evolution between exotic species and the organisms in the recipient communities. In this context, the "Novel Weapons Hypothesis" (Callaway \& Ridenour, 2004) and further developments (Cappuccino \& Arnason, 2006; Ehrenfeld, 2006) suggest that secondary chemical compounds produced by exotic invasive species could act as antimicrobial agents or invertebrate repellents in their areas of introduction, because these organisms have not had yet the opportunity to adapt to these compounds. Among secondary metabolites, polyphenols are both ubiquitous and diverse from one species to another (Haslam, 1989). They could be important modulators of breakdown processes, in particular through the inhibition of spore germination and hyphal growth of saprotrophic fungi (Grime et al., 1996; Hättenschwiler \& Vitousek, 2000). Polyphenols could also influence invertebrate activity that most often contributes substantially to litter breakdown (Cuffney et al., 1990; Hieber \& Gessner, 2002).

Current studies consider three criteria to select litter species in comparative studies of exotic and native plants: litter quality, phylogenetic or ecological proximity. Studies based on litter quality in low- order wooded streams have shown comparable breakdown rates among native and exotic species (Lecerf et al., 2007; Hladyz et al., 2009). Using phylogenetic proximity for 19 species pairs in a terrestrial environment, Godoy et al. (2009) found lower breakdown rates related to higher lignin litter concentration in exotic species. However, recognising that species co-occurrence and replacement are based on ecological niche similarity, in other studies exotic and native species have been selected according to ecological proximity in single pair experiments (Emery \& Perry, 1996; Bailey, Schweitzer \& Whitham, 2001; Harner et al., 2009). In the riparian areas of large rivers, hydrological disturbance generates contrasting environmental conditions resulting in a gradient of plant successional maturity that is overall organised from the river channel to the floodplain (Gregory et al., 1991; Naiman \& Décamps, 1997). It seems particularly appropriate for studies that focus on the ecological impact of plant invasions to select exotic and native species that have similar ecological characteristics and occur in the same successional stages.

Therefore, to assess the effect of a potential species replacement on organic matter degradation, we selected one pair of co-occurring native and exotic plant species in each of the four main successional stages identified within the riparian vegetation of a large river. Considering the ecological importance of herbaceous understory in the most mature successional stage (Malanson, 1993; Naiman, Décamps \& Mcclain, 2005), we selected a fifth pair of species in the understory plant formation. The selected natives were dominant species, the exotics being invasive ones. Indeed, Thompson, Hodgson \& Rich (1995) and Smith \& Knapp (2001) suggested that these two categories share similar biological traits that distinguish them from natives and exotics that occur at low occurrence (Thompson, 1994). Litter breakdown rates were determined in a natural pond, using an experimental design that allowed free access to invertebrates. We addressed two questions: (i) do litter degradation rates differ between exotic and native species with respect to their primary chemical composition and (ii) is detritivorous invertebrate community structure influenced by the geographical origin (exotic versus native) of the leaf litter with which they are associated? 


\section{Methods}

\section{Study species}

We selected five pairs of exotic and native plant species along the vegetation maturity gradient in the middle Garonne River (SW France, Fig. 1). Exotic species were chosen according to their high cooccurrence frequency and the closeness of their ecological characteristics to those of their native counterparts (Tabacchi \& Planty-Tabacchi, 2005). For each pair of exotic and native species, we assumed that the native is likely to be replaced by its ecologically related exotic counterpart. Selected exotics are neophytes (sensu Pyšek, 1995) and recognised as highly invasive in Europe (Daisie, 2010). Species were designated geographically as exotic or native in the context of their status in Europe.

\section{Experimental site}

We conducted litter-bag degradation experiments from November 2007 to November 2008 in a pond in the Garonne River floodplain downstream from its confluence with the Ariège River and upstream from the city of Toulouse $\left[43^{\circ} 31^{\prime} 36.96^{\prime \prime} \mathrm{N}, 1^{\circ} 25^{\prime} 38.24^{\prime \prime} \mathrm{E}\right.$, $147 \mathrm{~m}$ a.s.l.; about $150 \mathrm{~m}$ length (north-south orientation) $25 \mathrm{~m}$ width]. The pond is groundwater-fed and
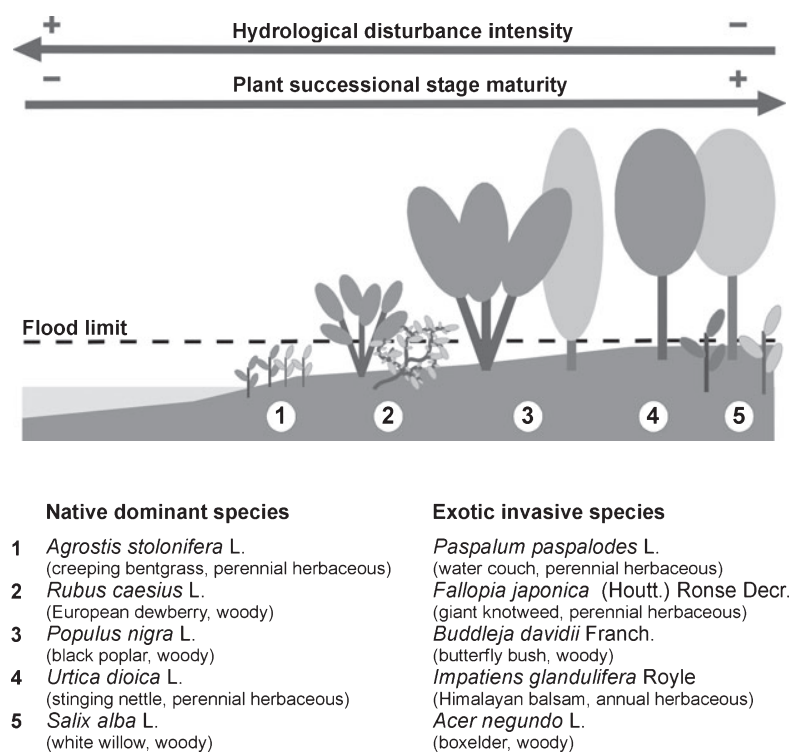

Fig. 1 Distribution of exotic and native species along gradients of hydrological disturbance and successional stages occurring within the riparian area. Flood limit corresponds to a flooding frequency of $1-3$ years. surrounded by a Populus nigra-dominated riparian forest. Riparian ponds and similar gravel-pits represent $31 \%$ of the waterbody's surface area within the studied middle Garonne River stretch. We chose this pond among four similar ones with comparable physicochemical characteristics because the vegetation on one bank allowed us to optimally set the bags and manipulate them without disturbing the benthos. Preliminary measurements showed that a gradient of oxygen, soluble reactive phosphorus (SRP), $\mathrm{NO}_{3}-\mathrm{N}$ and $\mathrm{NH}_{4}-\mathrm{N}$ concentration existed along the major axis of the pond. To encompass this gradient, we carried out in situ measurements and water sampling at the two extremities of the pond. We recorded water temperature every hour using Tinytalk (GeminiOrion, Chichester, UK) data loggers. We monitored $\mathrm{pH}$ ( $\mathrm{pH}$ 320; WTW GmbH, Weilheim, Germany), oxygen saturation (Oxi 330i; WTW $\mathrm{GmbH}$ ) and conductivity (HI 98311; Hanna instruments, Woonsocket, RI, U.S.A.) at the beginning of experiments and at each of the five litter-bag retrieval dates, at 09h00-09h30 AM (GMT 1.00). We also collected water samples for alkalinity determination by titration at $\mathrm{pH}$ $4.5 \pm 0.05$ (precision: $2 \%$ ). We filtered an aliquot of water in the field on a GF/F glass fibre filter (retention $0.7 \mu \mathrm{m}$; Whatman International Ltd, Florham Park, NJ, U.S.A.) for soluble reactive phosphorus (SRP) determination (Motomizu, Wakimoto \& Tôei, 1983; precision $5 \%$ ). We measured nitrate concentration by UV spectral deconvolution (Thomas et al., 1993) using an Anthelie 70MI instrument (precision: 2\%; Secomam, Ales, France). We carried out ammonium determination by the indophenol blue method (Apha, 1998; precision 5\%).

\section{Litter-bag experiment}

We collected plant leaves from litter traps in October 2007 and air-dried them at ambient temperature $\left(20^{\circ} \mathrm{C}\right)$. Rubus caesius, Fallopia japonica, Populus nigra, Buddleja davidii, Salix alba and Acer negundo litter consisted of leaves including petioles while Agrostis stolonifera, Paspalum distichum, Urtica dioica and Impatiens glandulifera litter included leaves and stems. We weighed 20 litter packs of $5 \pm 0.05$ g per species and sprayed them with deionised water to prevent break-up when we placed them into 10-mm-mesh bags. We placed four replicate blocks of five bags per plant litter species at regular intervals along the pond 
margin in November 2007. In order not to disturb the benthic layer, we anchored the bags to an iron bar driven into the bank and we carefully submerged the weighted bags at the bottom of the pond. We retrieved one bag per replicate block after 22, 55, 91, 203 and 359 days of exposure. During the retrieval, we placed a $150-\mu$ m-mesh net beneath the litter bag to collect material losses. Both the litter bag and the collected material were introduced into a zip-lock plastic bag containing filtered pond water. We estimated leaching of soluble compounds for each plant species from separate bags after $24 \mathrm{~h}$ of submersion (Gessner \& Schwoerbel, 1989).

In the laboratory, we gently rinsed leaves with demineralised water over a 200- $\mu \mathrm{m}$-mesh sieve to remove sediment. We identified leaf and stem parts of the studied species thanks to their morphological characteristics, and we removed exogenous organic matter. We collected invertebrates $(>200 \mu \mathrm{m})$ and preserved them in $70 \%$ ethanol. We dried litter samples at $105{ }^{\circ} \mathrm{C}$ until constant weight and weighed to the nearest $0.01 \mathrm{~g}$ and ground. We ashed a $250-\mathrm{mg}$ sample of the ground portions at $550{ }^{\circ} \mathrm{C}$ for $6 \mathrm{~h}$ and weighed to the nearest $0.01 \mathrm{mg}$ to determine organic matter content (ash-free dry mass, AFDM). We expressed remaining AFDM as percentage of the initial ADFM.

\section{Litter composition}

For each species, we dried four additional litter packs at $105{ }^{\circ} \mathrm{C}$ and weighed to the nearest $0.01 \mathrm{~g}$ to determine the initial dry litter mass. We used three subsamples of $0.5-\mathrm{mm}$ mesh ground litter to determine the contents of carbon, nitrogen ( $\mathrm{CHN}$ analyser, NA 2100; CE Instruments, Milan, Italy), phosphorus (acid digested litter ash method; Flindt \& Lillebø, 2005) and lignin (detergent method; Van Soest, 1963; Fibersac 24 Ankom, La Chapellesur-Erdre, France).

\section{Invertebrate processing}

We sorted invertebrates under a stereomicroscope, identified to the lowest possible taxonomic level (mainly species level) and counted individuals in each litter bag (Tachet et al., 2000). We assigned taxa to functional feeding groups (shredders, scrapers, filterers, gatherers and predators) according to the method described by Tachet et al. (2000). For species whose feeding behaviour spanned more than one feeding group, we allocated the number in each group in proportion to the corresponding activity estimated in the Tachet et al.'s fuzzy classification.

\section{Data analysis}

In contrast to the classical simple exponential model (Olson, 1963) that usually describes leaf litter breakdown kinetics, we used an additional constant to take refractory material at the end of the experiment into account:

$$
\mathrm{AFDM}_{t}=\mathrm{AFDM}_{0} \times \exp (-\mathrm{kt})+c
$$

where $\mathrm{AFDM}_{t}$ is the remaining mass of litter at time $t$, $\mathrm{AFDM}_{0}$ is the initial mass, $k$ is the breakdown rate and the constant $c$ corresponds to the remaining mass at the end of the experiment. As leaching is very short and distinct from the organism-mediated breakdown process, we did not include it in the model that starts at $24 \mathrm{~h}$ with measured AFDM after leaching. The statistical regression method allows the calculation of $95 \%$ intervals. We compared litter breakdown rates using a nested analysis of covariance (ANCOVA), followed by Tukey's test for post hoc pairwise comparisons. Log-transformed remaining AFDM was used as a response variable, species geographical origin (native versus exotic) and species as nested categorical factors, and time of exposure as a covariate. We performed a second ANCOVA model to test the effect of species growth form (herbaceous versus woody).

We analysed differences in chemical litter composition between total exotic and native species, all species and growth forms, with a nested analysis of variance (ANOVA) followed by Tukey's test for post hoc pairwise comparisons. Following a best-fit screening (Table curve 2D, version 5.1; Systat Software Inc., Chicago, IL, U.S.A.), we used simple exponential regression models $\left(y=a^{*} \exp \left(b^{*} x\right)\right)$ to describe the relationship between litter breakdown rates and litter primary chemical composition. The difference because of exotic vs. native origin was tested by applying a Mann-Whitney's test on regression residuals when the regression models were significant. As a predictor of degradability, we used the $\mathrm{C} / \mathrm{N}$ ratio as 
it is relevant to microbial activity (Herbert, 1976). The $\mathrm{C} / \mathrm{P}$ ratio was co-linearly related with the $\mathrm{C} / \mathrm{N}$ ratio.

We used invertebrate density (number of individuals $\mathrm{g} \mathrm{AFDM}^{-1}$ ) in each sample for invertebrate community analysis. We performed nested analysis of variance (ANOVA) to assess the differences in density of detritivorous invertebrates associated with litter, with log-transformed densities as the response variable. We used nested analysis of covariance (ANCOVA) to assess the differences in taxonomic richness of saprophytic invertebrates, with log-transformed abundances as covariates. We compared invertebrate community composition using analysis of similarity (ANOSIM with 1000 permutations). The number of replicates did not allow processing of ANOSIM among litter species for each sampling date, because of the low number of possible permutations, and we tested differences among species without distinguishing between sampling dates. We used the first four dates because very little litter remained in the bags at the fifth (autumnal) date and the invertebrate communities were expected to be attracted to recently fallen litter from the surrounding vegetation.

We modelled litter breakdown using TableCurve 2D (version 5.1; Systat Software Inc.), and we performed nested ANOVA, nested ANCOVA and multiple regressions with Statistica (version 6.0, Edition 98; Statsoft, Tulsa, OK, U.S.A.). We used PRIMER (version 5.2.2, Edition 2001; Primer-E Ltd, Ivybridge, U.K.) to carry out ANOSIM. We used type II sum of squares for ANOVA and ANCOVA analysis. We graphically verified normality and homogeneity of variance assumptions. When data transformation was necessary to approach normal distribution and homogeneity of variance, the nature of the transformation is specifically indicated earlier.

\section{Results}

\section{Leaf litter breakdown rate}

Water physicochemical characteristics indicated low oxygen saturation (41 and 15\%) and notably high $\mathrm{NH}_{4}-\mathrm{N}$ concentrations (43 and $99 \mu \mathrm{g} \mathrm{L}^{-1}$ ) in both south and north extremities of the pond (Table 1). Although we recorded a difference in site descriptors between the two extremities, no effect of the replicate samples on breakdown rate was observed (ANCOVA, $F=1.2, P=0.33$ ). Leaching resulted in $12.5-30.3 \%$
Table 1 Physical and chemical characteristics of water at the pond extremities. Mean (minimum, maximum) are shown for hourly temperature and oxygen saturation and mean $( \pm S E)$ for other parameters $(n=6)$

\begin{tabular}{lcc}
\hline Parameters & $\begin{array}{l}\text { South } \\
\text { extremity }\end{array}$ & $\begin{array}{l}\text { North } \\
\text { extremity }\end{array}$ \\
\hline Temperature $\left({ }^{\circ} \mathrm{C}\right)$ & $9.6(3.0,27.9)$ & $9.3(2.8,28.3)$ \\
Oxygen saturation $(\%)$ & $41(18,76)$ & $15(7,26)$ \\
$\mathrm{pH}$ & $7.48(0.10)$ & $7.55(0.08)$ \\
$\mathrm{Conductivity}$ at $25{ }^{\circ} \mathrm{C}$ & $858(20)$ & $801(20)$ \\
$\left.(\mu \mathrm{S} \mathrm{cm})^{-1}\right)$ & & \\
Alkalinity $\left(\mathrm{mg} \mathrm{CaCO}_{3} \mathrm{~L}^{-1}\right)$ & $365(6)$ & $328(9)$ \\
$\mathrm{SRP}\left(\mu \mathrm{g} \mathrm{L}^{-1}\right)$ & $4.0(2.3)$ & $12.1(5.4)$ \\
$\mathrm{NO}_{3}-\mathrm{N}\left(\mu \mathrm{g} \mathrm{L}^{-1}\right)$ & $552(114)$ & $26(18)$ \\
$\mathrm{NH}_{4}-\mathrm{N}\left(\mu \mathrm{g} \mathrm{L}^{-1}\right)$ & $43(16)$ & $99(28)$ \\
\hline
\end{tabular}

mass loss and was similar for exotic and native litter (nested ANOVA, $F=0.2, P=0.6$ ) (Table 2). Less than $20 \%$ of AFDM, corresponding to leaf veins and stems, remained for all species after the 1-year experiment (Fig. 2). The overall litter breakdown rate for exotic litter was not significantly higher than that for native litters (Fig. 2, Tables $2 \& 3$ ).

I. glandulifera, $U$. dioica and B. davidii degraded significantly faster than all other species (Fig. 2, Table 2). For I. glandulifera and $U$. dioica, the residual mass at the end of the experiment $(6.7 \pm 1.7 \%$ and $15.0 \pm 2.0 \%$ ) resulted in significant values for the constant $c$ in regression models (Table 2, all $P<0.03$ ) that correspond to the mass percentage of refractory stems. It is noteworthy that in contrast to other species, whether native or exotic, no B. davidii litter remained in bags 6 months prior to the next litterfall.

Table 2 Parameters of the breakdown model for the ten species in this study (grey highlighting indicates exotic species).

Leaching, per cent litter ash-free fry dry mass loss after leaching; $k$, litter breakdown rate; $c$, constant. Mean $( \pm \mathrm{SE}),(n=4)$

\begin{tabular}{lllr}
\hline & Leaching $(\%)$ & $\mathrm{k}\left(\mathrm{days}^{-1}\right)$ & $\mathrm{c}(\%)$ \\
\hline P. distichum & $13.2(1.0)$ & $0.0060(0.0013)$ & $0.0(8.8)$ \\
A. stolonifera & $17.6(1.9)$ & $0.0083(0.0019)$ & $10.1(5.6)$ \\
F. japonica & $12.5(0.9)$ & $0.0064(0.0012)$ & $0.0(6.8)$ \\
R. caesius & $21.8(1.0)$ & $0.0069(0.0016)$ & $0.0(7.2)$ \\
B. davidii & $27.7(2.2)$ & $0.0230(0.0019)$ & $0.0(1.7)$ \\
Populus nigra & $21.8(1.3)$ & $0.0066(0.0016)$ & $0.1(7.6)$ \\
I. glandulifera & $30.3(1.6)$ & $0.0575(0.0085)$ & $6.7(1.7)$ \\
U. dioica & $24.2(0.6)$ & $0.0463(0.0078)$ & $15.0(2.0)$ \\
A. negundo & $23.6(1.2)$ & $0.0103(0.0020)$ & $8.2(3.9)$ \\
S. alba & $27.4(2.3)$ & $0.0069(0.0019)$ & $0.0(8.1)$ \\
Exotics & $21.5(8.2)$ & $0.0116(0.0020)$ & $5.0(3.8)$ \\
Natives & $22.5(3.6)$ & $0.0074(0.0011)$ & $1.0(4.3)$ \\
\hline
\end{tabular}



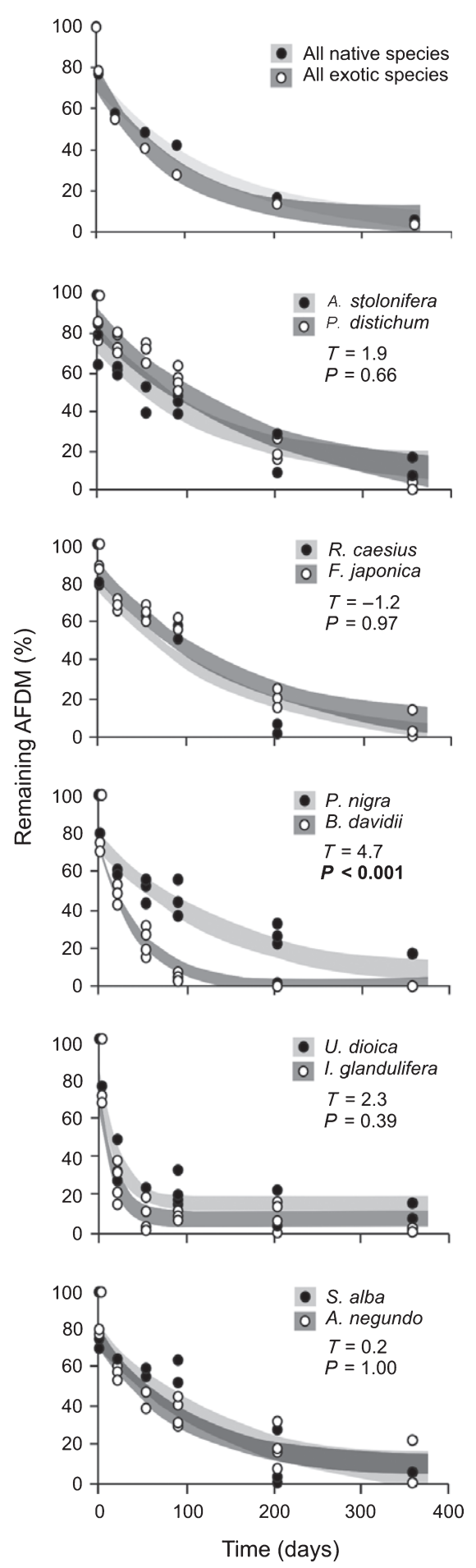

Fig. 2 Patterns $(n=4)$ in remaining ash-free dry mass (AFDM) of litter for the ten selected species (black circles native, open circles exotic). Dark and light shaded areas show $95 \%$ confidence intervals for exotic and native species, respectively (intervals between data points were calculated with the regression model). ANCOV A post hoc Tukey's test (T) and associated $P$-value $(P)$ are given.
Table 3 Nested ANCOVAs on remaining AFDM. "Origin" and "Time" refer to litter from exotic or native species and harvest date, respectively. $n=4$

\begin{tabular}{lrrrrc}
\hline Source of variation & d.f. & \multicolumn{1}{c}{ SS } & \multicolumn{1}{c}{ MS } & \multicolumn{1}{l}{$F$} & $P$ \\
\hline Origin & 1 & 0.5 & 0.5 & 0.1 & 0.79 \\
Species(origin) & 8 & 57.7 & 7.2 & 18.6 & $<\mathbf{0 . 0 0 0 1}$ \\
Time & 1 & 274.8 & 274.8 & 708.2 & $<0.0001$ \\
Origin*time & 1 & 0.02 & 0.02 & 0.05 & 0.83 \\
Species(origin)*time & 8 & 13.6 & 1.7 & 4.4 & $<\mathbf{0 . 0 0 0 1}$ \\
Error & 220 & 85.4 & 0.4 & & \\
Total & 239 & 428.6 & & &
\end{tabular}

Bold text indicated significant effect.

Comparisons among paired species showed that only the breakdown rate of $B$. davidii litter was significantly 3.5-fold higher than that of the native counterpart P. nigra (Fig. 2, Table 2). No effect of species growth form was found (ANCOVA, $F=0.01, P=0.91$ ).

\section{Leaf litter quality}

No effect of plant species geographical origin was observed, whether in relation to initial percentage of carbon (nested ANOVA, $F=0.03, P=0.86$ ), nitrogen $(F=0.2, \quad P=0.63)$, phosphorus $(F=3.1, P=0.12)$, lignin $(F=0.1, P=0.77)$ or the ratios of $\mathrm{C} / \mathrm{N}(F=0.3$, $P=0.60)$ and $\mathrm{C} / \mathrm{P}(F=2.7, P=0.14)$, whereas a species effect was found with each of these parameters (all $P<0.0001$ ) (Table 4). P. distichum litter appeared to be the most refractory to degradation with respect to its low phosphorus content $(0.10 \pm 0.00 \%)$ and high $\mathrm{C} / \mathrm{N}$ ratio $(39.5 \pm 0.1)$. U. dioica and I. glandulifera litter had the highest phosphorus contents (both $0.28 \pm 0.00 \%$ ) and the lowest $\mathrm{C} / \mathrm{N}$ ratios $(11.4 \pm 0.2$ and $14.0 \pm 0.1$ respectively). Litter from two plant species pairs, U. dioica/I. glandulifera and S. alba/A. negundo, had a very similar chemical composition. The litter of woody species had 3\% more carbon than those of herbaceous species $(F=6.2, P=0.04)$.

Separate nonlinear regressions showed that only the $\mathrm{C} / \mathrm{N}$ ratio explained a significant proportion of variance in litter breakdown rates (Fig. 3). There were no differences in the statistical dispersion of the regression residuals for exotic and native species (Mann-Whitney test; $U=4 ; P=0.1$ ). There was no relationship between litter breakdown rate and lignin content. The litter of the two herbaceous plants $P$. distichum and A. stolonifera displayed low lignin contents and degraded with breakdown rates close to 
Table 4 Initial chemical composition of litters. Species are sorted by increasing $\mathrm{C} / \mathrm{N}$ ratio. Mean values $(n=3)$ of per cent ash-free dry mass are shown $( \pm$ SE). An identical italic letter means no significant difference (nested ANOVA and Tukey's post hoc test; $P<0.05$ ). Grey-highlighted species are exotics. GF, growth form

\begin{tabular}{lllllll}
\hline & $\mathrm{C}(\%)$ & $\mathrm{N}(\%)$ & $\mathrm{P}(\%)$ & $\mathrm{C} / \mathrm{N}$ & $\mathrm{C} / \mathrm{P}$ & Lignin $(\%)$ \\
\hline U. dioica & $36.8(0.1)$ & $3.2(0.1)$ & $0.28(0.00) a$ & $11.4(0.2)$ & $133.0(1.2) a$ & $7.0(0.1) a d$ \\
I. glandulifera & $39.0(0.1)$ & $2.8(0.0)$ & $0.28(0.00) a$ & $14.0(0.1)$ & $138.7(0.3) a$ & $7.0(0.2) a$ \\
R. caesius & $43.7(0.1) c d$ & $2.4(0.1)$ & $0.21(0.00)$ & $17.9(0.2) a$ & $201.6(0.7)$ & $4.8(0.1)$ \\
A. negundo & $41.4(0.1) a$ & $2.2(0.1) a$ & $0.19(0.00)$ & $18.5(0.1) a c$ & $221.8(2.7)$ & $8.7(0.3) b c$ \\
B. davidii & $43.3(0.1) b c$ & $2.3(0.0) a$ & $0.18(0.00) b$ & $18.9(0.1) a c$ & $241.9(1.7) b$ & $6.2(0.2) a$ \\
S. alba & $43.8(0.1) d e$ & $2.3(0.0) a$ & $0.18(0.00) b$ & $19.1(0.1) c$ & $245.0(2.1) b$ & $7.9(0.2) c d$ \\
F. japonica & $43.1(0.1) b$ & $2.0(0.1)$ & $0.16(0.00)$ & $21.2(0.3) b$ & $270.7(1.6)$ & $9.1(0.2) b$ \\
A. stolonifera & $41.1(0.1) a$ & $1.9(0.1)$ & $0.37(0.01)$ & $21.9(0.3) b$ & $111.3(2.6)$ & $3.6(0.1)$ \\
Populus nigra & $44.3(0.1) e$ & $1.6(0.0)$ & $0.25(0.00)$ & $27.9(0.5)$ & $176.6(1.3)$ & $6.8(0.1) a$ \\
$P$. paspaloides & $41.4(0.1) a$ & $1.1(0.1)$ & $0.10(0.00)$ & $39.5(0.1)$ & $422.9(2.6)$ & $1.4(0.1)$ \\
Exotics & $41.6(1.0)$ & $2.1(0.3)$ & $0.18(0.00)$ & $22.5(5.7)$ & $259.2(1.7)$ & $6.5(1.8)$ \\
Natives & $41.9(1.9)$ & $2.3(0.3)$ & $0.26(0.00)$ & $19.6(3.5)$ & $173.5(1.3)$ & $6.0(1.0)$ \\
Herbaceous & $40.2(0.6)$ & $2.2(0.2)$ & $0.22(0.03)$ & $21.3(2.5)$ & $262.6(4.5)$ & $5.8(0.7)$ \\
Woody & $43.3(0.3)$ & $2.2(0.1)$ & $0.21(0.01)$ & $20.5(1.0)$ & $210.9(9.3)$ & $6.9(0.4)$ \\
Origin effect & $F=0.03$ & $F=0.2$ & $F=3.1$ & $F=0.3$ & $F=2.7$ & $F=0.1$ \\
& $P=0.86$ & $P=0.63$ & $P=0.12$ & $P=0.60$ & $P=0.14$ & $P=0.77$ \\
Species effect & $F=784.3$ & $F=470.1$ & $F=770.7$ & $F=1203.7$ & $F=1974.3$ & $F=209.4$ \\
& $P<\mathbf{0 . 0 0 0 1}$ & $P<0.0001$ & $P<0.0001$ & $P<0.0001$ & $P<0.0001$ & $P<0.0001$ \\
GF effect & $F=6.2$ & $F=0.0$ & $F=0.0$ & $F=0.02$ & $F=0.6$ & $F=0.6$ \\
& $P=\mathbf{0 . 0 4}$ & $P=0.92$ & $P=0.90$ & $P=0.89$ & $P=0.47$ & $P=0.47$ \\
\hline
\end{tabular}

Bold text indicated significant difference.

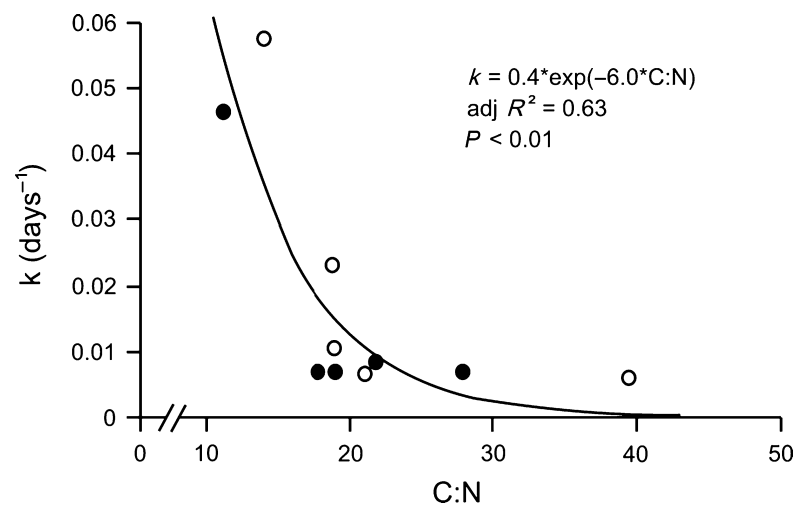

Fig. 3 Breakdown rates as a function of initial litter $\mathrm{C} / \mathrm{N}$ ratio. Black circles, natives; open circles, exotics. The line shown is the nonlinear regression with corresponding curve equation, adjusted partial determination coefficient and $P$-value.

those of the woody S. alba and A. negundo, which displayed high lignin contents (Tables $2 \& 4$ ). The high breakdown rates of $I$. glandulifera and $U$. dioica resulted from the fast degradation of the leaves whereas the lignin content was determined on the sampled mix of leaves and stems. Finally, phosphorus content showed a positive, but non-significant relationship with breakdown rates (adjusted $R^{2}<0.0001$; $P>0.35)$.

\section{Detritivorous invertebrate communities}

Invertebrate abundance was not related to remaining AFDM, whether the relationship was constructed using total detritivorous invertebrate abundance $(P=0.58)$ or shredder abundance $(P=0.63)$.

No effect of exotic versus native litter was found on the invertebrate assemblage (ANOVA, $F=0.0, P=0.98$ for densities; ANCOVA, $F=0.1, P=0.81$ for taxonomic richness). A significant effect was observed in the interaction "date" * "species" $(P<0.0001$ for all analyses). Maximum densities of total invertebrates occurred at 203 days with values in decreasing order for $B$. davidii $>I$. glandulifera $>P$. nigra $>R$. caesius $>$ F. japonica $>$ all other species (Fig. 4). Filterers represented the major proportion of invertebrates, except at 203 days, when gatherers were predominant.

The analysis of detritivorous invertebrate assemblage composition showed that shredders were dominated by Asellus aquaticus, Proasellus meridianus and Chironomidae, while several species of Cladocera were dominant in the filterer group. ANOSIM analysis showed that the composition of invertebrate assemblages associated with exotic litter was similar to that associated with native litter $(R=0.14, P=0.1)$. 

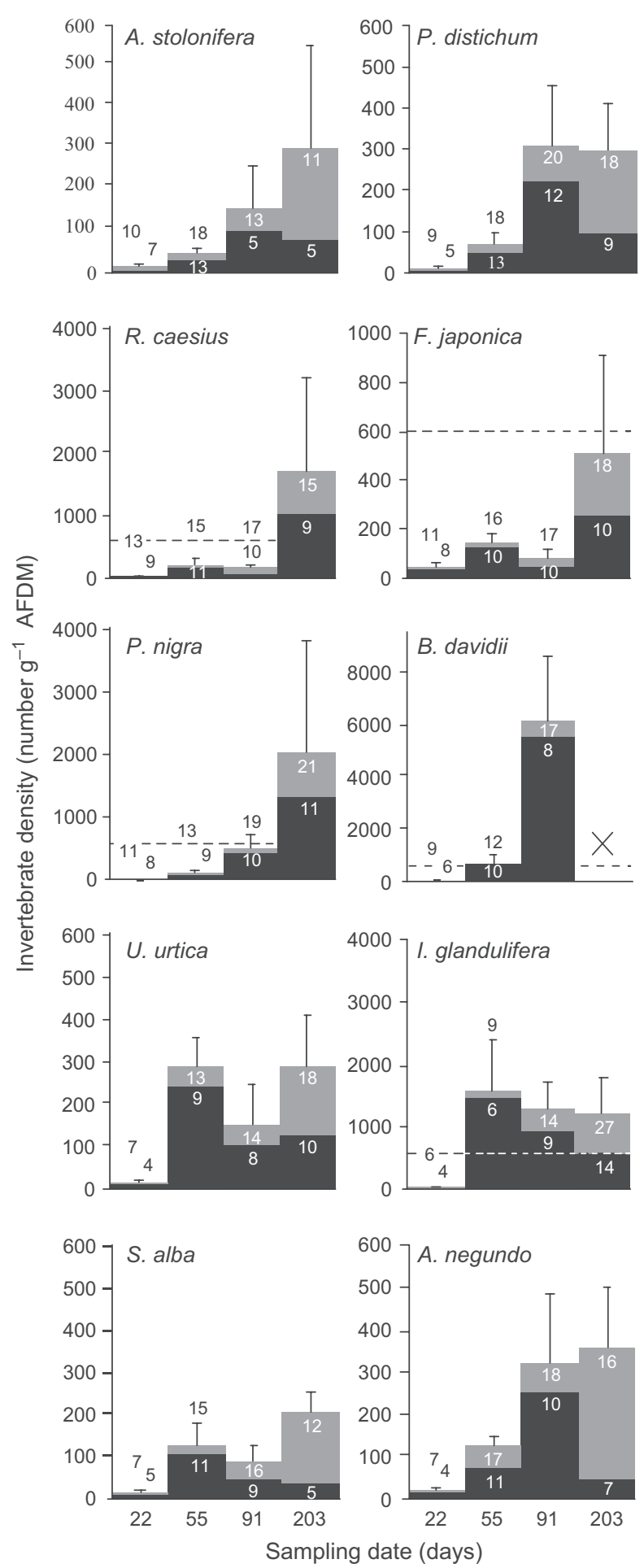

Fig. 4 Mean densities of detritivorous invertebrates. Black bars, filterer densities; grey bars all detritivorous invertebrates. Cross, no litter remaining in bags. Standard errors shown. Numbers in bars are mean taxonomic richness. The horizontal dashed line corresponds to 600 individuals.g ${ }^{-1}$ AFDM.
A strong effect of plant species was demonstrated ( $R=0.07, P=0.001)$. Post hoc comparisons showed that this was mainly attributed to differences between B. davidii, I. glandulifera and other species. Among selected pairs, differences were only detected for the $U$. dioica/I. glandulifera pair, but with low statistical significance $(R=0.09, P=0.049)$.

\section{Discussion}

Litter breakdown rate and species geographical origin

Our comparison of dominant native and co-occurring exotic invasive species has shown that litter breakdown rates of ecologically related plants in a temperate lentic ecosystem were primarily driven by the $\mathrm{C} / \mathrm{N}$ ratio, with no influence of plant geographical origin. Among pairs of selected ecologically related species, one native species had a lower breakdown rate than its exotic counterpart (P. nigra /B. davidii), but we did not observe differences within any of the other species pairs. Based on species ecological proximity, our selection of plant species produced results that are congruent with those of Hladyz et al. (2009). These authors observed no overall difference in a wooded stream between breakdown rates of several exotic and native species selected on the basis of litter quality and palatability. Studying phylogenetically paired species in terrestrial environments, Ashton et al. (2005) and Godoy et al. (2009) found that breakdown rates were partly driven by species geographical origin, through its influence on litter chemical composition. However, these studies showed opposite trends with, respectively, higher breakdown rates for exotic species, probably related to higher $\mathrm{N}$ litter content (Ashton et al., 2005), and lower ones, related to higher lignin litter content (Godoy et al., 2009). Moreover, breakdown differences were only 8 and $10 \%$ mass loss, indicating that, when observed, neither tendency is marked.

The growth form of the selected species only slightly influenced initial carbon content, with higher values for woody species, but had no influence on $\mathrm{C} / \mathrm{N}$ ratios and thus on litter breakdown rates. This apparently contrasts with the results of Godoy et al. (2009) who found growth form was the most influential factor in litter breakdown rates in a terrestrial environment. However, these authors found much 
higher lignin content in woody species (up to $46 \%$ ) compared with herbaceous species (down to $3 \%$ ) whereas the range displayed by our selected species was smaller (1.4-9.1\%). Given the range in our study, we did not find the previously observed negative relationship between litter breakdown rate and lignin content in woody species (Melillo, Aber \& Muratore, 1982; Gessner \& Chauvet, 1994; Ostrofsky, 1997). In particular, the low lignin contents of the herbaceous $P$. distichum and A. stonolifera were not associated with high breakdown rates. However, our results are consistent with those of Middleton et al. (1992) who showed that the breakdown rate of $P$. distichum was among the lowest of ten species in a tropical wetland. Here, the absence of a relationship between breakdown rate and lignin content may be related to the use of species from distinct botanical groups (monocots vs. dicots) and life forms (herbaceous vs. woody) that have different chemical compositions (Cornelissen, 1996; Cornelissen \& Thompson, 1997; Buranov \& Mazza, 2008).

\section{Detritivorous invertebrate communities and their drivers}

Invertebrate abundance and taxonomic richness associated with native and exotic plants were quite similar, in accordance with previous studies (Pereira, Graça \& Molles, 1998; Bailey et al., 2001; Braatne et al., 2007; Kappes, Lay \& Topp, 2007; Lecerf et al., 2007). Contrary to the "Novel Weapons Hypothesis" (Callaway \& Ridenour, 2004), we did not find lower invertebrate abundance or diversity in litter from species known to produce secondary chemical compounds that could act as invertebrate repellents (F. japonica: Beerling, Bailey \& Conolly, 1994; I. glandulifera : Lobstein et al., 2001; B. davidii: Houghton et al., 2003). Perhaps leaching has induced a loss of a significant proportion of these inhibitory compounds. In this context, other studies have also found comparable macroinvertebrate assemblages and breakdown rates between $F$. japonica and native woody species in lotic systems (Braatne et al., 2007; Lecerf et al., 2007).

The lack of a relationship between invertebrate abundance and remaining litter AFDM can be explained by the low level of shredder abundance because of constraining environmental conditions, mainly low oxygen and high $\mathrm{NH}_{4}-\mathrm{N}$ concentrations. Ammonium-ammonia $\left(\mathrm{NH}_{3}\right)$ equilibrium depends on temperature and $\mathrm{pH}$. In the pond, the calculated mean $\mathrm{NH}_{3}-\mathrm{N}$ concentration (Emerson et al., 1975) was $0.72 \mu \mathrm{g} \mathrm{L}^{-1}$, which is above the one recorded in streams where this toxic compound has been strongly suspected to be responsible for the absence of Gammarus (Lecerf et al., 2006; Baldy et al., 2007). As Asellus aquaticus is more resistant to ammonia than Gammarus pulex (Maltby, 1995), it is not surprising that the former species was the main shredder associated with litter in the pond. Beside the effect of low oxygen concentration per se, we cannot rule out additive or synergistic effects of high ammonia and low oxygen concentrations on invertebrate abundance and community structure. The low abundance of shredders also supports the hypothesis of dominance of microbial decomposition in the breakdown process as observed by Lecerf et al. (2006) and Baldy et al. (2007) in highly eutrophic and hypertrophic streams. Microbial activity produces fine particulate organic matter (Findlay \& Arsuffi, 1989) that is consumed by collector or filterer invertebrates (Cummins \& Klug, 1979). A related emerging pattern in our study is the early and large increase of filterer densities associated with plant species with fast litter breakdown, B. davidii and I. glandulifera, suggesting important microbial decomposition activity. High levels of fungal biomass and invertebrate abundance have already been observed in association with $B$. davidii litter (Hladyz et al., 2009). As observed in that study and ours, initial primary chemical composition did not clearly favour the high breakdown rates observed. However, the specific jelly-like litter mass observed during $B$. davidii litter degradation strongly suggests a particular polymer structure and/or organisation in this species, which in turn could be related to fast breakdown. Conversely, the low $\mathrm{C} / \mathrm{N}$ ratio and the high phosphorus content of I. glandulifera litter was expected to allow fast microbial decomposition accompanied by intense filterer activity. Finally high invertebrate densities associated with $F$. japonica and $P$. nigra litter could result in a habitat effect, as we preferentially found Chironomidae and Asellus individuals in numerous folds of $F$. japonica litter.

\section{Fast leaf litter breakdown and resource discontinuity}

In temperate ecosystems, breakdown of litter of various quality generally provides resource continuity until the next autumn's litterfall (Staelens et al., 2011). 
Although in our study I. glandulifera and $U$. dioica leaf litter exhibited high breakdown rates, the longer persistence of stem litter and the additional production of relatively refractory leaf litter from the surrounding canopy of woody species, notably S. alba, was able to maintain resource availability until the next autumn. In contrast, $B$. davidii leaf litter degraded 3.5-fold faster than its native counterpart P. nigra, resulting in the disappearance of litter 6 months before the next litterfall. As we have also observed this result in the terrestrial environment (data not shown), leaf litter resource continuity is expected to be broken where $B$. davidii is the only species present, or is very strongly dominant, in temperate riparian areas. In these ecosystems, under a natural or moderately modified flow regime and strong floodplain connectivity, recurrent flooding allows for litter of various types to be redistributed repeatedly within the habitat mosaic of the floodplain (Xiong \& Nilsson, 1997; Langhans, 2006). In such situations, overall litter turnover and consequent matter and energy transfers are expected to be altered only weakly by $B$. davidii inputs. In contrast, in areas showing natural or human-induced physical stability, the lack of litter transport by floods would result in dramatic reductions in inputs of slowly-degrading litter produced by other species. More generally, large stands of rapidly degrading leaf litter species would have limited effects when surrounding plant diversity is high and litter redistribution by floods is occurring. When either one or other condition is lacking, the induced discontinuity of plant litter resource would decrease niche opportunities for rare and specialised detritivores, with cumulative effects from year to year and a possible result of loss of biodiversity. We may also expect large consequences of invasions by exotic species that produce poor leaf quality litter, as a very slow breakdown rate would result in limited nutrient cycling (Dassonville, 2008; Hladyz et al., 2009). Invasions by plants producing litter subject to extreme breakdown rates have to be considered a potential threat for biodiversity.

\section{Acknowledgments}

We are grateful to Celinde Ricoveri, Thomas Lheureux, Michael Taland, Didier Lambrigot, Sylvain Lamothe, Lydie Roques, Raphaëlle Leclerc and Bruno Buatois for laboratory assistance. We thank Jean Moro making the field access easier. We are also grateful to two anonymous referees and Colin Townsend for helpful comments that improved the manuscript content and presentation. M. Bottollier-Curtet benefited from a French MESR fellowship.

\section{References}

Alpert P. (2006) The advantages and disadvantages of being introduced. Biological Invasions, 8, 1523-1534.

Apha (1998) Standard Methods for the Examination of Water and Wastewater. American Public Health Association, American Water Works Association and Water Environment Federation, Washington, DC.

Ashton I.W., Hyatt L.A., Howe K.M., Gurevitch J. \& Lerdau M.T. (2005) Invasive species accelerate decomposition and litter nitrogen loss in a mixed deciduous forest. Ecological Applications, 15, 1263-1272.

Bailey J.K., Schweitzer J.A. \& Whitham T.G. (2001) Salt cedar negatively affects biodiversity of aquatic macroinvertebrates. Wetlands, 21, 442-447.

Baldy V., Gobert V., Guerold F., Chauvet E., Lambrigot D. \& Charcosset J.Y. (2007) Leaf litter breakdown budgets in streams of various trophic status: effects of dissolved inorganic nutrients on microorganisms and invertebrates. Freshwater Biology, 52, 1322-1335.

Beerling D.J., Bailey J.P. \& Conolly A.P. (1994) Fallopia Japonica (Houtt.) Ronse Decraene. Journal of Ecology, 82, 959-979.

Braatne J.H., Mažeika S., Sullivan P. \& Chamberlain E. (2007) Leaf decomposition and stream macroinvertebrate colonisation of japanese knotweed, an invasive plant species. International Review of Hydrobiology, 92, 656-665.

Buranov A.U. \& Mazza G. (2008) Lignin in straw of herbaceous crops. Industrial Crops and Products, 28, 237-259.

Cadish G. \& Giller K.E. (1997) Driven by Nature: Plant Litter Quality and Decomposition. CAB International, Wallingford.

Callaway R.M. \& Ridenour W.M. (2004) Novel weapons: invasive success and the evolution of increased competitive ability. Frontiers in Ecology and the Environment, 2, 436-443.

Cappuccino N. \& Arnason J.T. (2006) Novel chemistry of invasive exotic plants. Biology Letters, 2, 189-193.

Cornelissen J.H.C. (1996) An experimental comparison of leaf decomposition rates in a wide range of temperate plant species and types. Journal of Ecology, 84, 573-582.

Cornelissen J.H.C. \& Thompson K. (1997) Functional leaf attributes predict litter decomposition rate in herbaceous plants. New Phytologist, 135, 109-114. 
Coûteaux M.M., Bottner P. \& Berg B. (1995) Litter decomposition, climate and litter quality. Trends in Ecology \& Evolution, 20, 63-66.

Cuffney T.F., Wallace J.B. \& Lugthart G.J. (1990) Experimental-evidence quantifying the role of benthic invertebrates in organic-matter dynamics of headwater streams. Freshwater Biology, 23, 281-299.

Cummins K.W. \& Klug K.W. (1979) Feeding ecology of stream invertebrates. Annual Review of Ecology and Systematics, 10, 147-172.

Cummins K.W., Wilzbach M.A., Gates D.M., Perry J.B. \& Taliferro W.B. (1989) Shredders and Riparian vegetation - leaf litter that falls into streams influences communities of stream invertebrates. BioScience, 39, 24-30.

Daisie (2010) European Invasive Alien Species Gateway. http:/ / www.europe-aliens.org/index.do.

Dassonville N. (2008) Impact des Plantes Exotiques Envahissantes sur le Fonctionnement des Écosystèmes en Belgique. PhD Thesis, Université libre de Bruxelles, Bruxelles.

Ehrenfeld J.G. (2003) Effects of exotic plant invasions on soil nutrient cycling processes. Ecosystems, 6, 503-523.

Ehrenfeld J.G. (2006) A potential novel source of information for screening and monitoring the impact of exotic plants on ecosystems. Biological Invasions, 8, 1511-1521.

Ehrenfeld J.G. (2010) Ecosystem consequences of biological invasions. Annual Review of Ecology and Systematics, 41, 59-80.

Emerson K., Lund R.E., Thurston R.V. \& Russo R.C. (1975) Aqueous ammonia equilibrium calculations: effect of $\mathrm{pH}$ and temperature. Journal of the Fisheries Research Board of Canada, 32, 2379-2383.

Emery S.L. \& Perry J.L. (1996) Decomposition rates and phosphorus concentrations of purple loosestrife (Lythrum salicaria) and cattail (Typha spp.) in fourteen Minnesota wetlands. Hydrobiologia, 323, 129-138.

Findlay S.E.G. \& Arsuffi T.L. (1989) Microbial growth and detritus transformation during decomposition of leaf litter in a stream. Freshwater Biology, 21, 261-269.

Flindt M.R. \& Lillebø A.I. (2005) Determination of total nitrogen and phosphorus in leaf litter. In: Methods to study litter decomposition: A practical guide (Eds M.A.S. Graça, F. Bärlocher \& M.O. Gessner ), pp. 45-50. Springer Verlag, Berlin.

Gessner M.O. \& Chauvet E. (1994) Importance of stream microfungi in controlling breakdown rates of leaf litter. Ecology, 75, 1807-1817.

Gessner M.O. \& Schwoerbel J. (1989) Leaching kinetics of fresh leaf-litter with implications for the current concept of leaf-processing in streams. Archiv fuer Hydrobiologie, 115, 81-90.
Godoy O., Castro-Díez P., Van Logtestijn R.S.P., Cornelissen J.H.C. \& Valladares F. (2009) Leaf litter traits of invasive species slow down decomposition compared to Spanish natives: a broad phylogenetic comparison. Oecologia, 162, 781-790.

Gregory S.V., Swanson F.J., Mckee W.A. \& Cummins K.W. (1991) An ecosystem perspective of riparian zones. BioSciences, 41, 540-551.

Grime J.P., Cornelissen J.H.C., Thompson K. \& Hodgson J.G. (1996) Evidence of a causal connection between anti-herbivore defence and the decomposition rate of leaves. Oikos, 77, 489-494.

Hanson B.J., Cummins K.W., Barnes J.R. \& Carter M.W. (1984) Leaf litter processing in aquatic systems: a two variable model. Hydrobiologia, 111, 21-29.

Harner M.J., Crenshaw C.L., Abelho M., Stursova M., Shah J.J.F. \& Sinsabaugh R.L. (2009) Decomposition of leaf litter from a native tree and an actinorhizal invasive across riparian habitats. Ecological Applications, 19, 1135-1146.

Haslam E. (1989) Plant Polyphenols. Vegetable Tannins Revisited. Cambridge University Press, Cambridge.

Hättenschwiler S. \& Vitousek P.M. (2000) The role of polyphenols in terrestrial ecosystem nutrient cycling. Trends in Ecology \& Evolution, 15, 238-243.

Herbert D. (1976) Stoichiometric aspect of microbial growth. In: Continuous Culture: 6 Applications and New Fields (Eds A.C.R. Dean), pp. 1-30. Ellis Horwood, New York.

Hieber M. \& Gessner M.O. (2002) Contribution of stream detrivores, fungi, and bacteria to leaf breakdown based on biomass estimates. Ecology, 83, 1026-1038.

Hladyz S., Gessner M.O., Giller P.S., Pozo J. \& Woodward G. (2009) Resource quality and stoichiometric constraints on stream ecosystem functioning. Freshwater Biology, 54, 957-970.

Houghton P.J., Mensah A.Y., Iessa N. \& Liao Y.H. (2003) Terpenoids in Buddleja: relevance to chemosystematics, chemical ecology and biological activity. Phytochemistry, 64, 385-393.

Kappes H., Lay R. \& Topp W. (2007) Changes in different trophic levels of litter-dwelling macrofauna associated with giant knotweed invasion. Ecosystems, 10, 734-744.

Langhans S.D. (2006) Riverine Floodplain Heterogeneity as a Controller of Organic Matter Dynamics and Terrestrial Invertebrate Distribution. PhD Thesis, Swiss federal institute of technology, Zurich.

Lecerf A., Usseglio-Polatera P., Charcosset J.Y., Lambrigot D., Bracht B. \& Chauvet E. (2006) Assessment of functional integrity of eutrophic streams using litter breakdown and benthic macroinvertebrates. Archiv fuer Hydrobiologie, 165, 105-126. 
Lecerf A., Patfield D., Boiche A., Riipinen M.P., Chauvet E. \& Dobson M. (2007) Stream ecosystems respond to riparian invasion by Japanese knotweed (Fallopia japonica). Canadian Journal of Fisheries and Aquatic Sciences, 64, 1273-1283.

Leishman M.R., Haslehurst T., Ares A. \& Baruch Z. (2007) Leaf trait relationships of native and invasive plants: community- and global-scale comparisons. New Phytologist, 176, 635-643.

Liao C., Peng R., Luo Y., Zhou X., Wu X., Fang C. et al. (2008) Altered ecosystem carbon and nitrogen cycles by plant invasion: a meta-analysis. New Phytologist, 177, 706-714.

Lobstein A., Brenne X., Feist E., Metz N., Weniger B. \& Anton R. (2001) Quantitative determination of naphthoquinones of Impatiens species. Phytochemical Analysis, 12, 202-205.

Malanson G.P. (1993) Riparian Landscapes. Cambridge University Press, Cambridge.

Maltby L. (1995) Sensitivity of the crustaceans Gammarus pulex (L.) and Asellus aquaticus (L.) to short-term exposure to hypoxia and unionized ammonia: Observations and possible mechanisms. Water Research, 29, 781-787.

Melillo J.M., Aber J.D. \& Muratore J.F. (1982) Nitrogen and lignin control of hardwood leaf litter decomposition dynamics. Ecology, 63, 621-626.

Middleton B.A., Van Der Valk A.G., Williams R.L., Mason D.H. \& Davis C.B. (1992) Litter decomposition in an Indian monsoonal wetland overgrown with Paspalum distichum. Wetlands, 12, 37-44.

Motomizu S., Wakimoto T. \& Tôei K. (1983) Spectrophotometric determination of phosphate in river waters with molybdate and malachite green. The Analyst, 108, 361-367.

Naiman R.J. \& Décamps H. (1997) The ecology of interfaces: Riparian zones. Annual Review of Ecology and Systematics, 28, 621-658.

Naiman R.J., Décamps H. \& Mcclain M.E. (2005) Riparia: Ecology, Conservation and Management of Streamside Communities. Elsevier Academic Press, Burlington.

Olson J.S. (1963) Energy storage and the balance of producers and decomposers in ecological systems. Ecology, 44, 322-331.

Ostrofsky M.L. (1997) Relationship between chemical characteristics of autumn-shed leaves and aquatic processing rates. Journal of the North American Benthological Society, 16, 750-759.

Pereira A.P., Graça M.A.S. \& Molles M. (1998) Leaf litter decomposition in relation to litter physico-chemical properties, fungal biomass, arthropod colonization, and geographical origin of plant species. Pedobiologia, 42, 316-327.
Petersen H. \& Luxton M. (1982) A comparative analysis of soil fauna populations and their role in decomposition processes. Oikos, 39, 288-388.

Planty-Tabacchi A.M., Tabacchi E., Naiman R.J., Deferrari C. \& Decamps H. (1996) Invasibility of species-rich communities in riparian zones. Conservation Biology, 10, 598-607.

Pyšek P. (1995) On the terminology used in plant invasion studies. In: Plant Invasions. General Aspects and Special Problems (Eds P. Pyšek, K. Prach , M. Rejmanek \& M. Wade), p. 274. SPB Academic Publishing, Amsterdam.

Richardson D.M., Holmes P.M., Esler K.J., Galatowitsch S.M., Stromberg J.C., Kirkman S.P. et al. (2007) Riparian vegetation: degradation, alien plant invasions, and restoration prospects. Diversity and Distributions, 13, 126-139.

Schnitzler A., Hale B.W. \& Aslum E.M. (2007) Examining native and exotic species diversity in European riparian forests. Biological Conservation, 138, 146-156.

Smith M.D. \& Knapp A.K. (2001) Physiological and morphological traits of exotic, invasive exotic, and native plant species in tallgrass prairie. International Journal of Plant Sciences, 162, 785-792.

Staelens J., Nachtergale L., De Schrijver A., Vanhellemont M., Wuyts K. \& Verheyen K. (2011) Spatio-temporal litterfall dynamics in a 60-year-old mixed deciduous forest. Annals of Forest Science, DOI:10.1007/s13595011-0010-5.

Stohlgren T.J., Bull K.A., Otsuki Y., Villa C.A. \& Lee M. (1998) Riparian zones as havens for exotic plant species in the central grasslands. Plant Ecology, 138, 113-125.

Swift M.J., Heal O.W. \& Anderson J.M. (1979) Decomposition in Terrestrial Ecosystems. University of California Press, Berkeley.

Tabacchi E. \& Planty-Tabacchi A.M. (2005) Exotic and native plant community distributions within complex riparian landscapes: a positive correlation. Ecoscience, 12, 412-423.

Tachet H., Richoux P., Bournaud M. \& Usseglio-Polatera P. (2000) Invertébrés D'eau Douce. Systématique, Biologie, Écologie. CNRS EDITIONS, Paris.

Thomas O., Theraulaz F., Domeizel M. \& Massiani C. (1993) UV spectral deconvolution: a valuable tool for wastewater quality determination. Environmental Technology, 14, 1187-1192.

Thompson K. (1994) Predicting the fate of temperate species in response to human disturbance and global change. In: NATO Advanced Research Workshop on Biodiversity, Temperate Ecosystems and Global Change (Eds T.J.B. Boyle \& C.E.B. Boyle ), pp. 61-76. SpringerVerlag, Berlin. 
Thompson K., Hodgson J.G. \& Rich T.C.G. (1995) Native and alien invasive plants: more of the same? Ecography, 18, 390-402.

Thorp J.H. \& Delong M.D. (1994) The riverine productivity model: an heuristic view of carbon sources and organic processing in large river ecosystems. Oikos, 70, 305-308.

Van Soest P.J. (1963) Use of detergents in the analysis of fibrous feeds II. A rapid method for the determination of fiber and lignin. Journal of the Association of Official Analytical Chemists, 46, 829-835.

Vitousek P.M., D'antonio C.M., Loope L.L. \& Westbrooks R. (1996) Biological invasions as global environmental change. American Scientist, 84, 468-478.
Webster J.R. \& Benfield E.F. (1986) Vascular plant breakdown in freshwater ecosystems. Annual Review of Ecology and Systematics, 17, 367-394.

Xiong S. \& Nilsson C. (1997) Dynamics of leaf litter accumulation and its effects on riparian vegetation: a review. Botanical Review, 63, 240-264.

Xiong S. \& Nilsson C. (1999) The effects of plant litter on vegetation: a meta-analysis. Journal of Ecology, 87, 984994. 